\title{
Diagnosis Miskonsepsi Terhadap Konsep Hukum Newton dan Penerapannya pada Peserta Didik: Four-Tier Diagnotic Test
}

\author{
Yuni Sahara $^{1)} *$ Erniwati $^{2)}$, La Sahara $^{3)}$ \\ 1)* Mahasiswa Jurusan Pendidikan Fisika, Universitas Halu Oleo, Indonesia \\ ${ }^{2), 3)}$ Dosen Jurusan Pendidikan Fisika, Universitas Halu Oleo, Indonesia \\ *Korespondensi Email: yunisahara@gmail.com
}

\begin{abstract}
Abstrak: Penelitian ini bertujuan: (1) memperoleh gambaran miskonsepsi terhadap materi pokok hukum Newton dan penerapannya pada peserta didik kelas X SMKN 2 Kendari; (2) menunjukkan sub konsep miskonsepsi paling tinggi pada hukum Newton dan penerapannya. Populasi penelitian sedemikian sebagai sampel adalah seluruh peserta didik kelas X Teknik Elektronika SMKN 2 Kendari yang terdiri dari 2 kelas sebanyak 56 orang. Pengambilan data dalam penelitian berupa tes diagnostik four-tier yang berjumlah 25 nomor dan wawancar. Wawancara dilakukan sebagai pendukung untuk mengkonfirmasi hasil dari tes yang telah dilakukan. Data dianalisis secara kualitatif, dari hasil analisis data diperoleh kesimpulan: (1) Miskonsepsi yang terjadi pada peserta didik setelah melakukan tes diagnostik berkategori sedang dengan persentase sebesar $39,07 \%$. (2) Miskonsepsi tertinggi teridentifikasi pada materi hukum I Newton dengan persentase sebesar 47,32\%, di susul sub-konsep aplikasi hukum Newton 46,88\%, sub-konsep hukum II Newton 41,07\%, subkonsep penerapan hukum Newton 36,61\%, sub konsep hukum III Newton 35,71\% dan yang terakhir subkonsep jenis-jenis gaya 35,46\%.
\end{abstract}

Kata Kunci: Miskonsepsi; Four-Tier Diagnotic Test

Abstract: The purpose of this research is: (1) to get a description of the misconceptions of grade X students of SMKN 2 Kendari on the subject matter of Newton's law and its application; (2) shows the highest concept of misconception in Newton's law and its application. The research population as a sample was all students of class X in Electrical Engineering at SMKN 2 Kendari consisting of 2 classes of 56 people. Data collection in the research was a four-tier diagnostic test totaling 25 numbers and interviews. Interviews were conducted as a support to confirm the results of the tests that have been carried out. Data were analyzed qualitatively, from the results of the data analysis conclusions were obtained: (1) Misconceptions that occur in students after undergoing diagnostic tests are in the moderate categorized with a percentage of $39.07 \%$. (2) The highest misconception was identified in Newton's first law material with a percentage of $47.32 \%$, followed by Newton's legal application sub-concept 46.88\%, Newton's II legal sub-concept 41.07\%, Newton's 36 , 61\%, Newton's third law sub concept $35.71 \%$ and the last sub-concept types of force $35.46 \%$.

Keywords: Misconception; Four-Tier Diagnotic Test

\section{PENDAHULUAN}

Fisika merupakan cabang Ilmu Pengetahuan Alam yang sangat menunjang perkembangan ilmu pengetahuan dan teknologi. Untuk mempelajari dan memahami pelajaran fisika tidak mudah, karena selain materi dan bahan yang begitu luas, peserta didik juga dituntut untuk melakukan kegiatan praktikum, memahami gejala alam dan diharapkan menemukan gagasan-gagasan baru. Kemampuan peserta didik dalam memahami dan menguasai suatu konsep, mengaitkan satu konsep dengan konsep lain masih menjadi permasalahan yang dihadapi oleh peserta didik di sekolah (Erniwati, dkk. 2020). Permasalahan disebabkan oleh beberapa faktor, Faktor pertama yaitu peserta didik tidak terbiasa menggunakan daya nalarnya, tetapi terbiasa menghafal dari pada memahami konsep yang terkandung di dalam materi pelajaran (Kawuri, dkk. 2019). Hal tersebut menimbulkan pengetahuan yang di peroleh peserta didik hanya bersifat sementara. Faktor kedua yaitu pengetahuan awal yang dimiliki peserta didik tidak lain bersumber dari orang tua, teman, lingkungan, dan pengalaman keseharian yang bisa jadi menimbulkan adanya miskonsepsi. 
Miskonsepsi adalah kesalahan penafsiran konsep yang tidak sesuai dengan apa yang dimaksud oleh para ilmuwan (Suparno, 2013)

Berdasarkan hasil penelitian yang dilakukan oleh Ayu Suci Lestari (2015) menyebutkan bahwa peserta didik kelas X SMKN 4 Mataram tahun pelajaran 2014/2015 pada konsep suhu persentase peserta didik yang tidak memahami konsep sebesar $30,45 \%$, peserta didik yang mengalami miskonsepsi sebesar $11,53 \%$, dan peserta didik yang memahami konsep sebesar 57,36\%. Pada konsep kalor, persentase peserta didik yang tidak memahami konsep sebesar $41,74 \%$, peserta didik yang mengalami miskonsepsi sebesar $16,44 \%$, dan peserta didik yang memahami konsep sebesar $42,70 \%$.

Berdasarkan observasi awal yang telah dilakukan, diperoleh informasi bahwa miskonsepsi mungkin saja terjadi pada peserta didik kelas $\mathrm{X}$ SMKN 2 Kendari. Ketika guru melakukan proses pengajaran dalam pembelajaran fisika, sebagian guru mengalami kendala tentang bagaimana cara menanamkan konsep secara tepat dalam diri peserta didik, karena sebenarnya dalam benak peserta didik sudah terdapat pengetahuan dan pengalaman dalam dirinya tentang gejala fisika yang dianggap sama persis dengan konsep yang ada dalam fisika. Beberapa peserta didik masih kesulitan dalam menghubungkan keterkaitan antara konsep suatu materi maupun saat dihadapkan dengan pertanyaan atau soal mengenai konsep fisika yang menyebabkan adanya miskonsepsi. Karena konsep yang dimiliki peserta didik tidak hanya berjangka waktu pendek, melainkan berjangka waktu panjang yang dapat digunakan saat mereka telah lulus sekolah dan melanjutkan bekerja dibidang yang mereka kuasai. Miskonsepsi hampir terjadi dalam semua konsep fisika salah satunya pada materi hukum Newton.

Hukum Newton dan penerapannya merupakan salah satu konsep fisika yang berkaitan dengan fenomena alam. Fenomena tersebut adalah jatuhnya sebuah benda selalu mengarah ke bawah, hal tersebut karena adanya gaya gravitasi dan gerak yang mempengaruhinya. Menurut hasil penelitian yang dilakukan oleh Zulvita \& Halim (2017) menyatakan bahwa adanya miskonsepsi pada peserta didik dengan persentase rata-rata hasil yang diperoleh yaitu, peserta didik mengalami tahu konsep sebanyak $15,4 \%$, peserta didik yang mengalami Not Confident (CN) sebanyak 7\%, peserta didik yang mengalami tidak tahu konsep (TTK) sebanyak 30\% dan peserta didik yang mengalami miskonsepsi (M) sebanyak 44,8\%. Salah satu cara untuk mengetahui miskonsepsi pada peserta didik adalah dengan tes diagnostik. Tes diagnostik four-tier merupakan soal pilihan ganda dengan pilihan alasan jawaban dan tingkat keyakinan alasan jawaban yang digunakan untuk mengetahui secara tepat, memastikan kelemahan dan kekuatan peserta didik pada pelajaran tertentu (Ismail, dkk. 2015). Amalia (2018) dalam penelitiannya menyatakan bahwa peserta didik yang paham konsep sebesar $37,78 \%$, peserta didik yang tidak paham konsep sebesar $8,89 \%$ dan peserta didik yang miskonsepsi sebesar $16,67 \%$ pada materi hukum Newton dan penerapannya.

Berdasarkan permasalahan yang telah dipaparkan, penulis ingin meneliti miskonsepsi tentang Hukum Newton dan Penerapannya. Judul penelitian ini Diagnosis Miskonsepsi Terhadap Materi Hukum Newton Dan Penerapannya Pada Peserta Didik Kelas X SMKN 2 Kendari Menggunakan Four-Tier Diagnostic Test. Pokok permasalahan yang dikaji pada penelitian ini adalah (1) Bagaimana gambaran miskonsepsi terhadap materi pokok hukum Newton dan penerapannya pada peserta didik kelas X SMKN 2 Kendari ?; (2). Sub konsep apa saja yang menunjukkan miskonsepsi paling tinggi pada materi pokok hukum Newton dan penerapannya ?. Tujuan dari penelitian ini adalah sebagai sumber literatur dan referensi mengenai miskonsepsi siswa khusunya pada pelajaran fisika.

\section{METODE}

Jenis penelitian ini adalah penelitian deskriptif kualitatif. Sampel dalam penelitian ini adalah peserta didik kelas X Teknik Elektronika SMKN 2 Kendari yang tersebar dari kelas X AUVI Adan X AUVI B. Distribusi populasi penelitian berdasarkan kelas dan jenis kelamin dapat dilihat pada Tabel 1. 
Tabel 1. Distribusi populasi penelitian berdasarkan kelas dan jenis kelamin.

\begin{tabular}{|c|c|c|c|c|}
\hline \multirow[b]{2}{*}{ No. } & \multirow[b]{2}{*}{ Kelas } & \multicolumn{2}{|c|}{ Jenis Kelamin } & \multirow[b]{2}{*}{$\begin{array}{l}\text { Jumlah Peserta Didik } \\
\text { (orang) }\end{array}$} \\
\hline & & $\begin{array}{c}\text { Laki-laki } \\
\text { (orang) }\end{array}$ & $\begin{array}{l}\text { Perempuan } \\
\text { (orang) }\end{array}$ & \\
\hline 1. & X AUVI A & 29 & 0 & 29 \\
\hline 2. & X AUVI B & 24 & 3 & 27 \\
\hline & Jumlah & & & 56 \\
\hline
\end{tabular}

Teknik pengumpulan data nilai miskonsepsi dilakukan dengan memberikan tes diagnostik tentang hukum Newton dan penerapannya. Tes yang digunakan berbentuk tes diagnostik four-tier pilihan ganda disertai alasan yang dilengkapi dengan tingkat keyakinan peserta didik.

Instrumen yang digunakan diagnostik berbentuk four-tier terdiri dari 25 soal. Setiap soal terdiri dari 4 tingkat yang meliputi: (1) (one-tier) berupa soal pilihan ganda, (2) (two-tier) berupa tingkat keyakinan terhadap jawaban, (3) (three-tier) berupa alasan terkait jawaban dan (4) (four-tier) berupa tingkat keyakinan terhadap alasan. Dimana peserta didik harus mengerjakan soal dengan 4 tahap. Tahap pertama, peserta didik menjawab soal pilihan ganda dengan memilih salah satu jawaban yang sudah disediakan. Tahap kedua, peserta didik memberikan tingkat keyakinan terhadap jawaban yang telah dipilih. Tahap ketiga, peserta didik memilih alasan dari jawaban yang dipilih. Tahap keempat, peserta didik memberikan tingkat keyakinan terhadap alasan yang dipilih. Soal yang digunakan dalam penelitian ini adalah soal yang dikembangkan oleh Amalia (2018) dan Nasafi (2018), dimana soal yang ada sebelum digunakan untuk meneliti, soal tersebut di uji validitas ulang oleh peneliti.

Berdasarkan data yang diperoleh setelah tes diagnostik, selanjutnya dilakukan wawancara untuk mengkonfirmasi jawaban peserta didik. Wawancara yang dilakukan bersifat terstruktur yang artinya pertanyaan dan urutannya secara garis besar telah dipersiapkan terlebih dahulu, sehingga peneliti dapat secara sistematis bertanya dan memperoleh informasi. Instrumen yang digunakan berupa pedoman wawancara. Kegiatan wawancara melibatkan beberapa orang dari peserta didik yang telah diketahui mengalami miskonsepsi setelah memeriksa hasil tes diagnostic.

Teknik analisis yang digunakan adalah analisis deskriptif persentase. Tahap I: Mengelompokkan terlebih dahulu jawaban peserta didik disetiap butir soal ke dalam beberapa kategori yaitu paham konsep, paham sebagian, miskonsepsi dan tidak paham konsep sesuai dengan kriteria yang terdapat pada Tabel 2.

Tabel 2. Kategori kombinasi jawaban four-tier diagnostic test.

\begin{tabular}{clllll}
\hline No & \multicolumn{1}{c}{ Kategori } & Tier $\mathbf{1}$ & Tier 2 & Tier 3 & Tier 4 \\
\hline 1 & Paham Konsep & Benar & Yakin & Benar & Yakin \\
2 & Paham sebagian & Salah & Yakin & Benar & Yakin \\
3 & Paham sebagian & Salah & Tidak & Benar & Yakin \\
4 & Miskonsepsi & Benar & Yakin & Salah & Yakin \\
5 & Miskonsepsi & Benar & Tidak & Salah & Yakin \\
6 & Miskonsepsi & Salah & Yakin & Salah & Yakin \\
7 & Miskonsepsi & Salah & Tidak & Salah & Yakin \\
8 & Tidak paham konsep & Benar & Yakin & Benar & Tidak \\
9 & Tidak Paham konsep & Benar & Yakin & Salah & Tidak \\
10 & Tidak paham konsep & Benar & Tidak & Benar & Yakin \\
11 & Tidak paham konsep & Benar & Tidak & Benar & Tidak \\
12 & Tidak paham konsep & Benar & Tidak & Salah & Tidak \\
13 & Tidak paham konsep & Salah & Yakin & Benar & Tidak \\
14 & Tidak paham konsep & Salah & Yakin & Salah & Tidak \\
15 & Tidak paham konsep & Salah & Tidak & Benar & Tidak \\
16 & Tidak paham konsep & Salah & Tidak & Benar & Tidak \\
\hline
\end{tabular}


Tahap II: Setelah diketahui kategori dari hasil jawaban peserta didik, peneliti menghitung persentase peserta didik yang paham konsep, paham sebagian, miskonsepsi, dan tidak paham konsep

$$
P=\frac{f}{N} x 100 \%
$$

Dengan:

$P=$ angka persentase kelompok,

$f=$ jumlah peserta didik tiap kelompok,

$N=$ jumlah individu (jumlah seluruh peserta didik yang menjadi subjek penelitian).

Hasil dari perhitungan nilai persentase dengan persamaan tersebut dituliskan dalam bentuk tabel pada materi hukum Newton dan penerapannya. Menurut Rahmawati, dkk. (2017) untuk menghitung persentase peserta didik dapat menggunakan persamaan (1).

seperti yang terlihat pada Tabel 3. Tabel tersebut menjelaskan seberapa besar nilai persentase peserta didik yang mengalami paham konsepi, paham sebagian, miskonsepsi dan tidak paham konsep. Beberapa kategori miskonsepsi berdasarkan besar persentasenya dapat dilihat pada Tabel 3(Suwarna, 2013).

Tabel 3 Kategori persentase tingkat miskonsepsi.

\begin{tabular}{ccc}
\hline No & Persentase & Kategori \\
\hline 1 & $0-30 \%$ & Rendah \\
2 & $31-60 \%$ & Sedang \\
3 & $61-100 \%$ & Tinggi \\
\hline
\end{tabular}

HASIL PENELITIAN

1. Persentase Jawaban Hasil Tes Diagnotik Four-Tier Test
Persentase jawaban hasil tes diagnostik four-tier test peserta didik SMKN 2 Kendari pada materi hukum Newton dan penerapannya dapat dilihat pada Tabel 4.

Tabel 4. Persentase jawaban hasil tes diagnostik four-tier test

\begin{tabular}{|c|c|c|c|c|}
\hline \multirow[b]{2}{*}{ No Soal } & \multicolumn{4}{|c|}{ Persentase Tingkat Pemahaman Peserta Didik } \\
\hline & $\begin{array}{c}\text { Paham Konsep } \\
(\%)\end{array}$ & $\begin{array}{c}\text { Paham } \\
\text { sebagian }(\%)\end{array}$ & $\begin{array}{c}\text { Miskonsepsi } \\
(\%)\end{array}$ & $\begin{array}{l}\text { Tidak Paham } \\
\text { Konsep (\%) }\end{array}$ \\
\hline 1 & 48,21 & 17,86 & 28,57 & 5,35 \\
\hline 2 & 30,36 & 12,5 & 30,36 & 26,79 \\
\hline 3 & 44,64 & 0 & 33,93 & 21,43 \\
\hline 4 & 33,93 & 5,36 & 35,71 & 25 \\
\hline 5 & 35,71 & 32,14 & 19,64 & 12,5 \\
\hline 6 & 35,71 & 5,36 & 44,64 & 14,29 \\
\hline 7 & 35,71 & 0 & 55,36 & 8,93 \\
\hline 8 & 41,07 & 5,36 & 44,64 & 8,93 \\
\hline 9 & 39,29 & 1,79 & 50 & 8,93 \\
\hline 10 & 46,43 & 19,64 & 28,57 & 5,36 \\
\hline 11 & 17,86 & 19,64 & 53,57 & 8,93 \\
\hline 12 & 46,43 & 10,71 & 32,14 & 10,71 \\
\hline 13 & 17,86 & 28,57 & 39,29 & 14,29 \\
\hline 14 & 37,5 & 17,86 & 25 & 19,64 \\
\hline 15 & 21,43 & 21,43 & 41,07 & 16,07 \\
\hline 16 & 71,43 & 3,57 & 17,86 & 7,14 \\
\hline 17 & 37,5 & 23,21 & 26,79 & 12,5 \\
\hline 18 & 33,93 & 3,57 & 50 & 12,5 \\
\hline 19 & 39,29 & 1,79 & 55,36 & 3,57 \\
\hline 20 & 55,36 & 7,14 & 35,71 & 1,79 \\
\hline 21 & 48,21 & 8,93 & 41,07 & 1,79 \\
\hline 22 & 53,57 & 1,79 & 39,29 & 5,36 \\
\hline
\end{tabular}




\begin{tabular}{ccccc}
23 & 33,93 & 14,29 & 46,43 & 5,36 \\
24 & 33,93 & 12,5 & 46,43 & 7,14 \\
25 & 28,57 & 5,36 & 55,36 & 10,71 \\
\hline Rata-rata & $\mathbf{3 8 , 7 1}$ & $\mathbf{1 1 , 2 1}$ & $\mathbf{3 9 , 0 7}$ & $\mathbf{1 1 , 0 0}$ \\
\hline
\end{tabular}

Berdasarkan Tabel 4 terlihat bahwa dari 25 soal yang diujiakn diperoleh bahwa aspek paham konsep $38,71 \%$, Paham sebagian $11,21 \%$, Miskonsepsi $39,07 \%$, dan tidak paham konsep 11,00\%. Hasil ini menunjukkan bahwa kebanyakan siswa mengalami miskonseo dibandingkan dengan siswa yang paham konsep. Akan tetapi miskonsepsi disini bentuk karena siswa lebih banyak menghafal dibandingkan dengan memahami konsep yang diberikan.

2. Persentase Rata-Rata Jawaban Peserta Didik Secara Keseluruhan

Persentase rata-rata jawaban peserta didik secara keseluruhan dapat dilihat pada Gambar 1.

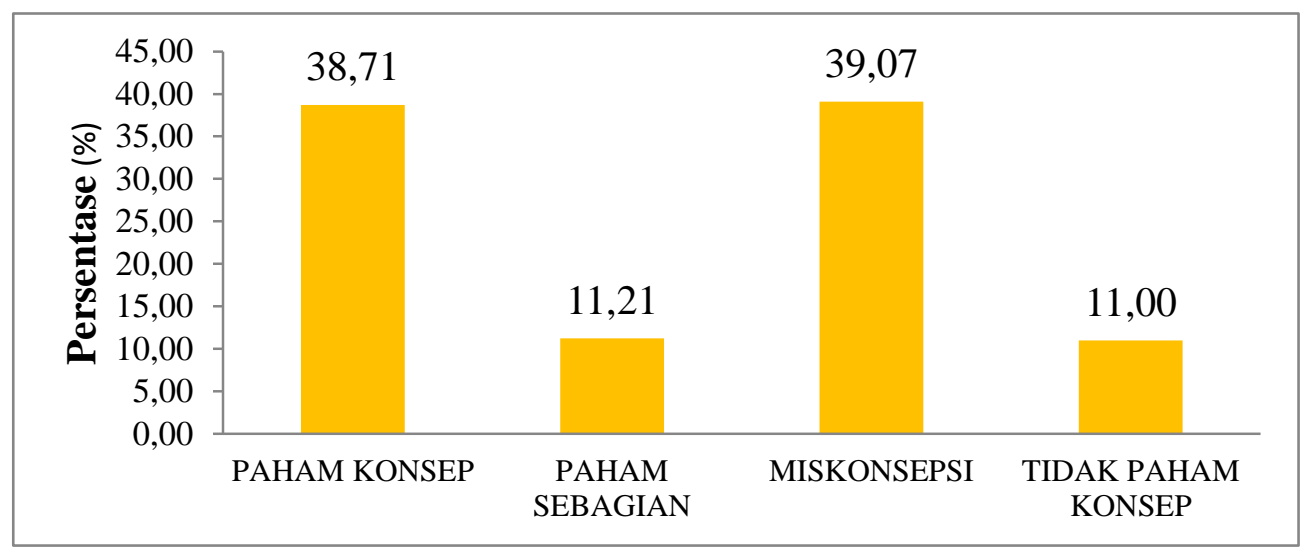

Gambar 1. Persentase rata-rata jawaban peserta didik secara keseluruhan.

Gambar 1 menunjukkan bahwa secara keseluruhan kategori miskonsepsi memiliki nilai persentase paling tinggi $39,07 \%$. Selanjutnya paham konsep dengan persentase $38,71 \%$, Paham sebagian dengan persentase $11,21 \%$ dan tidak paham konsep dengan persentase sebesar $11,00 \%$.
3. Persentase Tingkat Paham konsep, Paham
Sebagian, Miskonsepsi dan Tidak
PahamKonsep Peserta Didik untuk Masing-
masing Sub-Konsep.
Persentase tingkat paham konsep, paham sebagian, miskonsepsi dan tidak paham konsep peserta didik untuk masing-masing sub-konsep dapat dilihat pada Gambar 2.

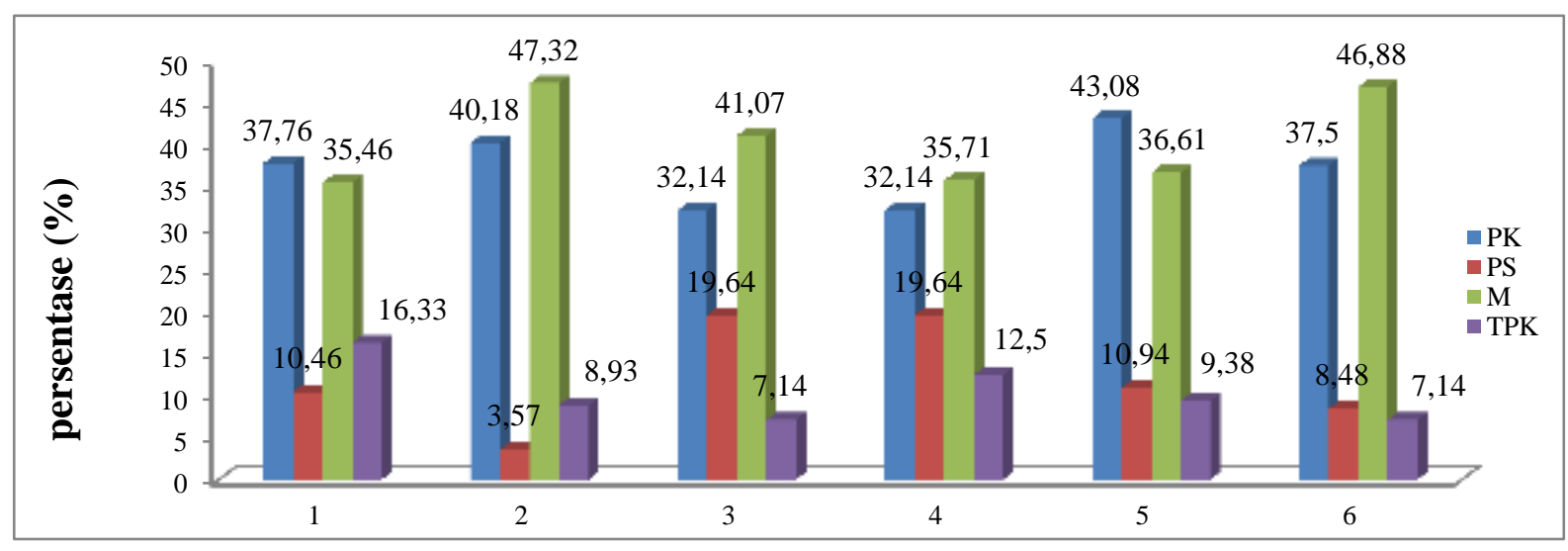

Gambar 2 Persentase Peserta Didik Pada Masing-masing Sub-Konsep: (1) Jenis-Jenis Gaya, (2) Hukum I Newton, (3) Hukum II Newton, (4) Hukum III Newton, (5) Penerapan Hukum Newton (6) Aplikasi Hukum Newton. 
Keterangan :

$\square \quad$ Untuk kategori Paham Konsep (PK)

$\square$ Untuk kategori Paham Sebagian/menebak (PS)

$\square$ Untuk kategori Miskonsepsi (M)

$\square$ Untuk kategori Tidak Paham Konsep (TPK)

Berdasarkan Gambar 22 menunjukkan bahwa tingkat paham konsep paling tinggi terdapat pada sub-konsep penerapan hukum Newton dengan persentase sebesar 43,08\%. Selanjutnya untuk tingkat paham sebagian paling tinggi terdapat pada sub-konsep hukum II Newton dan hukum III Newton dengan persentase keduanya sebesar $19,64 \%$. Sedangkan untuk tingkat miskonsepsi paling terdapat pada sub-konsep hukum I Newton dengan persentase sebesar 47,32\%. Dan untuk

tingkat tidak paham konsep paling tinggi terdapat pada sub-konsep jenis-jenis gaya dengan persentase sebesar $16,33 \%$.

\section{Persentase Miskonsepsi Peserta Didik untuk Masing-Masing Tipe pada Setiap Sub-Konseo}

Persentase tingkat paham konsep, paham sebagian, miskonsepsi dan tidak paham konsep peserta didik untuk masing-masing sub-konsep dapat

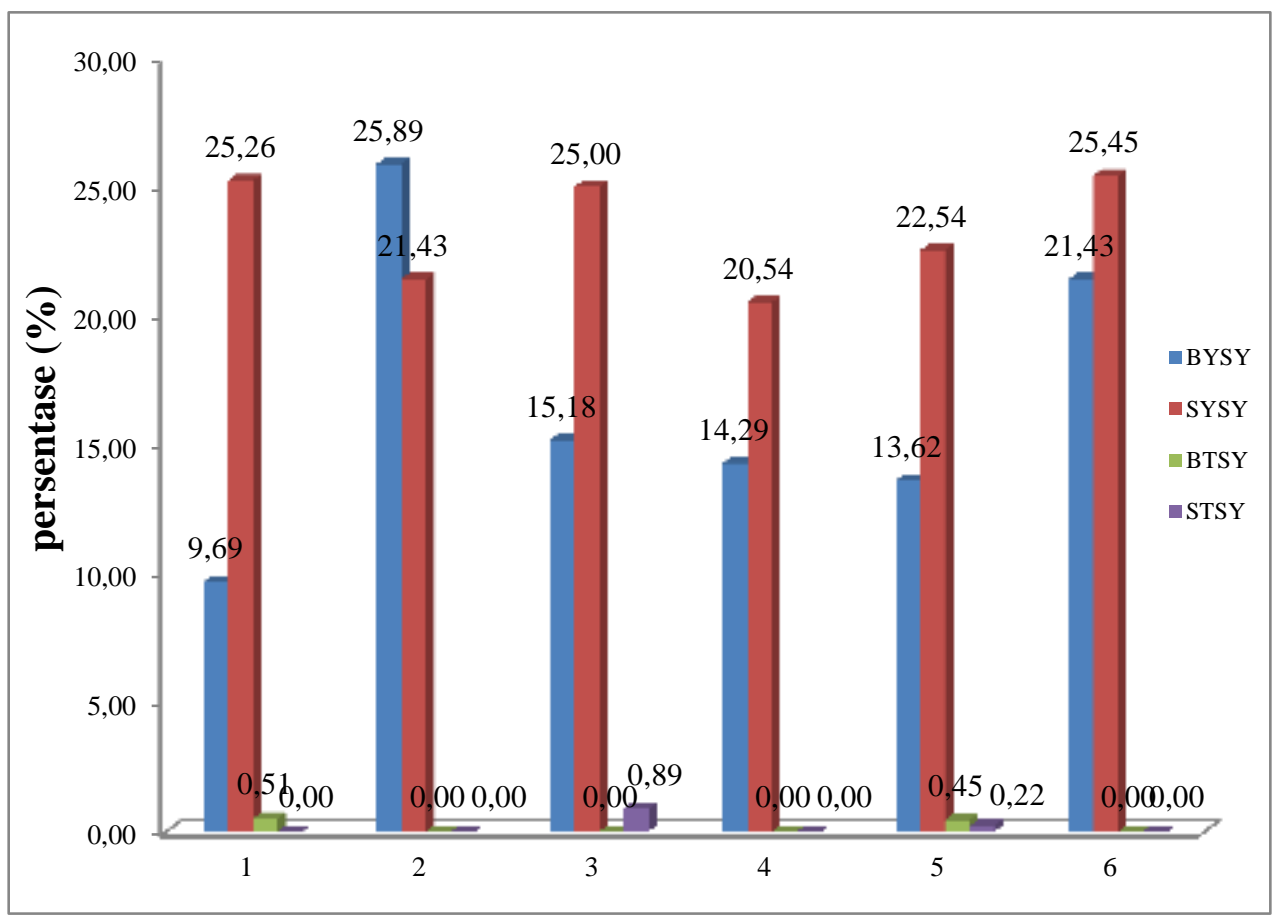

Gambar 3. Persentase Miskonsepsi Peserta Didik untuk Masing-masing Tipe pada Setiap SubKonsep: (1) Jenis-Jenis Gaya, (2) Hukum I Newton, (3) Hukum II Newton, (4) Hukum III Newton, (5) Penerapan Hukum Newton (6) Aplikasi Hukum Newton.

Keterangan:

$\square$ BYSY : Benar-Yakin-Salah-Yakin

$\square$ SYSY : Salah-Yakin-Salah-Yakin

$\square$ BTSY : Bena-Tidak-Salah-Yakin

$\square$ STSY : Salah-Tidak-Salah Yakin

Dari Gambar 3 menunjukkan bahwa peserta didik yang mengalami miskonsepsi paling banyak dengan memilih tipe jawaban benar yakin salah yakin terdapat pada sub-konsep hukum I Newton dengan persentase sebesar $25,89 \%$. Selanjutnya tipe jawaban salah yakin salah yakin paling banyak terdapat pada sub-konsep aplikasi hukum Newton dengan persentase sebesar $25,45 \%$. Sedangkan tipe jawaban benar tidak salah yakin paling banyak terdapat pada sub-konsep jenis-jenis gaya dengan 
persentase sebesar $0,51 \%$. Dan untuk tipe jawaban salah tidak salah yakin paling banyak terdapat pada sub-konsep hukum II Newton dengan persentase sebesar $0,89 \%$.

\section{PEMBAHASAN}

Diagnosis miskonsepsi peserta didik dilakukan untuk mengetahui tingkat pemahaman peserta didik selama proses pembelajaran. Dalam penelitian ini terdapat empat kategori pemahaman yaitu paham konsep, paham sebagian, miskonsepsi dan tidak paham konsep. Hasil analisis data setelah dilakukan tes diagnostik four-tier menunjukkan bahwa dari 56 peserta didik yang menjadi objek penelitian, 38,71\% termasuk kategori paham konsep, sedangkan sisanya 39,07\% mengalami miskonsepsi, $11,21 \%$ termasuk kategori paham sebagian atau menebak tidak percaya diri atas jawaban, dan $11,00 \%$ peserta didik tidak tahu konsep. Sehingga secara garis besar peserta didik yang mengalami miskonsepsi lebih besar dibandingkan peserta didik yang paham konsep, dapat dikatakan bahwa tingkat miskonsepsi peserta didik pada materi hukum Newton dan penerapannya berkategori sedang.

Miskonsepsi yang terungkap paling tinggi pada materi jenis-jenis gaya diantaranya terdapat pada soal nomor 7 yaitu sebesar $55,36 \%$. Berdasarkan wawancara yang dilakukan hal ini disebabkan peserta didik belum mampu menganalisis besar nilai gaya normal yang ada pada sebuah benda, dimana peserta didik beranggapan bahwa gaya normal searah dengan gaya tekan dan berlawanan dengan gaya berat. Muna (2018) menyatakan bahwa 72\% peserta didik beranggapan ada gaya pada kotak diam tersebut karena diketahui besar koefisien gesek statis dan kinetis sehingga mengalami kesulitan dalam menganalisis soal dengan teliti.

Miskonsepsi paling tinggi yang terungkap pada materi hukum I Newton diantaranya terdapat pada soal nomor 9 yaitu sebesar $50 \%$, peserta didik beranggapan bahwa benda bergerak lurus dengan kelajuan tetap. Berdasarkan wawancara yang telah dilakukan hal ini disebabkan peserta didik belum mampu menjelaskan resultan gaya pada sebuah benda yang bernilai nol. Sedangkan pada materi hukum II Newton terdapat pada soal nomor 11 yaitu sebesar $53,57 \%$ dimana peserta didik beranggapan bahwa soal tersebut merupakan hukum I Newton yang menjelaskan kecenderungan suatu benda untuk mempertahankan keadaannya. Berdasarkan wawancara yang telah dilakukan hal ini disebabkan peserta didik belum mampu memahami pengertian hukum II Newton. Hal serupa dilaporkan oleh
Amalia (2018), menemukan $1,11 \%$ peserta didik mengalami miskonsepsi dikarenakan peserta didik belum bisa membedakan bunyi hukum I Newton dan bunyi hukum II Newton.

Miskonsepsi paling tinggi pada materi hukum III Newton diantaranya terdapat pada soal nomor 13 yaitu sebesar 39, 29\%, dimana peserta didik menganggap bahwa gaya aksi reaksi merupakan pasangan gaya yang bekerja pada dua benda yang sama, memiliki nilai tidak sama dan gaya aksi searah dengan arah gaya reaksi. Berdasarkan wawancara yang dilakukan hal ini disebabkan peserta didik belum mampu menjelaskan konsep hukum III Newton yang bekerja pada benda. Sedangkan, Eviyanti (2016) menemukan 40,88\% peserta didik mengalami miskonsepsi pada materi hukum III Newton (aksi-reaksi). Peserta didik secara konsisten menentukan bahwa terdapat pasangan gaya aksireaksi pada benda yang diam diatas meja.

Miskonsepsi tertinggi pada materi penerapan hukum Newton terdapat pada soal nomor 19 yaitu sebesar 55,36\%, peserta didik beranggapan bahwa gaya yang bekerja pada benda berbanding lurus dengan massa dan percepatannya sama dengan nol. Berdasarkan wawancara yang telah dilakukan menunjukkan bahwa peserta didik belum mampu memahami besar nilai gaya yang memengaruhi gerak benda. Senada dengan Muna (2018), peserta didik mengalami miskonsepsi dengan persentase miskonsepsi sebesar 52\%. Peserta didik kurang mengulang dan memecahkan soal hitungan sehingga peserta didik memahami bahwa nilai kecepatan yang diketahui adalah nilai percepatan.

Miskonsepsi tertinggi pada materi aplikasi hukum Newton diantaranya terdapat pada soal nomor 25 yaitu sebesar 55,36\%. Dimana berdasarkan wawancara yang telah dilakukan peserta didik menganggap bahwa tembok menerima reaksi dari batu bata. Senada dengan Amalia (2018), menemukan persentase sebesar 30\% peserta didik mengalami miskonsepsi karena beranggapan bahwa batu bata menerima aksi dari tembok. Untuk dapat menjawab pertanyaan tersebut, peserta didik di tuntut menguasai konsep hukum Newton III apabila dihubungkan dengan sebuah benda.

Miskonsepsi sendiri memiliki empat tipe jawaban yaitu benar yakin salah yakin, salah yakin salah yakin, benar tidak salah yakin dan salah tidak salah yakin. Kebanyakan peserta didik yang mengalami miskonsepsi memilih dua tipe jawaban yang berbeda. Jawaban pertama peserta didik memilih tipe jawaban benar pada tingkat pertama, yakin pada tingkat kedua, salah pada tingkat ketiga dan yakin 
pada tingkat keempat. Jawaban kedua peserta didik memilih tipe jawaban salah pada tingkat pertama, yakin pada tingkat kedua, salah pada tingkat ketiga dan yakin pada tingkat keempat. Diantara empat tipe jawaban tersebut peserta didik lebih banyak menjawab pada tipe jawaban salah yakin salah yakin. Artinya bahwa pengetahuan maupun alasan yang dipahami peserta didik tersebut masih keliru. Kusairi \& Zulaikha (2017) yang menyatakan bahwa miskonsepsi dapat terjadi akibat keterbatasan dalam pengamatan dan dari sumber informasi yang tidak akurat.

Dari hasil wawancara yang telah dilakukan dengan beberapa orang peserta didik yang mengalami miskonsepsi diperoleh bahwa miskonsepsi terjadi salah satunya disebabkan oleh diri peserta didik. Dimana peserta didik merasa tertantang dalam mengerjakan instrumen diagnostik berbentuk four-tier test. Hal ini disebabkan peserta didik dituntut untuk berpikir lebih keras memahami setiap konsep dan peserta didik juga sangat bertanggung jawab untuk memberikan jawaban yang paling sesuai dengan pikiran dan keyakinan mereka. Four-tier test bagi peserta didik merupakan bentuk soal yang sangat jarang mereka temui dan berbeda dari bentuk soal yang selama ini sering mereka kerjakan, kemudian uraian soal dan alasan yang cukup panjang membuat peserta didik membutuhkan waktu yang cukup lama untuk menjawab soal-soal tersebut. Hal tersebut dikudung dari Andriyani \& Prihandoko (2017) mengatakan bahwa pembelajaran fisika saat ini sering mengalami kendala yang disebabkan peserta didik pasif, kurang minat belajar sehingga membuat peserta didik kurang memahami konsep da terjadi miskonsepsi. Miskonsepsi yang disebabkan oleh minat yang kurang dalam belajar fisika juga diungkapkan oleh Fitria (2017) miskonsepsi dapat ditimbulkan karena minat dan usaha peserta didik yang rendah dalam belajar fisika.

Terjadinya persentase miskonsepsi yang sangat tinggi mengartikan bahwa belum tercapainya sebuah tujuan pembelajaran menyebabkan Peserta didik belum dapat mengembangkan kemampuan berpikirnya dan secara tidak langsung dapat menurunkan kualitas pendidikan (Sri Astutik, 2018). Hal ini disebabkan karena pemahaman peserta didik yang kurang atau sedikitnya informasi yang diperoleh. Miskonsepsi perlu diketahui sehingga ada upaya-upaya yang dilakukan untuk diperbaiki agar peserta didik tidak mengalami miskonsepsi yang berkelanjutan. Penjelasan diatas membuktikan bahwa dengan menggunakan diagnostik tes four-tier dapat mengungkapkan miskonsepsi yang dialami oleh peserta didik.

\section{KESIMPULAN}

Berdasarkan hasil analisis dari tes diagnostik four-tier untuk mendiagnosis miskonsepsi terhadap materi pokok hukum Newton dan penerapannya pada peserta didik kelas X SMKN 2 Kendari dapat disimpulkan bahwa: (1) Miskonsepsi yang terjadi terhadap materi pokok hukum Newton dana penerapannya pada peserta didik setelah melakukan tes diagnostik berkategori sedang dengan persentase sebesar 39,07\%; (2) Miskonsepsi tertinggi teridentifikasi pada sub-konsep materi hukum I Newton dengan persentase sebesar $47,32 \%$, di susul sub-konsep aplikasi hukum Newton 46,88\%, subkonsep hukum II Newton 41,07\%, sub-konsep penerapan hukum Newton 36,61\%, sub konsep hukum III Newton $35,71 \%$ dan yang terakhir subkonsep jenis-jenis gaya $35,46 \%$.

Saran Untuk peneliti selanjutnya, penelitian ini dapat dikembangkan dengan menambahkan cara menanggulangi miskonsepsi yang terjadi, sehingga miskonsepsi peserta didik dapat dikurangi semaksimal mungkin, sehingga penelitian yang dihasilkan lebih berkualitas dan bermanfaat

\section{DAFTAR PUSTAKA}

Amalia, L. T. (2018). Identifikasi Miskonsepsi Menggunakan Tes Diagnostik Four-Tier Pada Konsep Hukum Newton dan Penerapannya Terhadap Siswa Kelas X di SMAN 5 Kota Serang (Bachelor's thesis, Jakarta: FITK UIN Syarif Hidayatullah Jakarta).

Andriyani, N. F., \& Prihandono, T. (2017). Identifikasi Pemahaman Konsep Siswa Kelas XII Pada Materi Pokok Gelombang Cahaya Di SMA. FKIP e-PROCEEDING, 2(1), 5-5.

Erniwati, E., Sukariasih, L., Hunaidah, H., Sahara, L., Hasrida, H., Sirih, M., \& Fayanto, S. (2020). Analysis of Difficulty of Science Learning-Based Multi-Representation. Jurnal Pendidikan Fisika, 8(3), 263-278.

Eviyanti. 2016. Analisis Miskonsepsi Fisika Pokok Bahasan Hukum Newton Tentang Gerak Dengan Teknik Certainty Of Response Index (CRI) pada Siswa Kelas X Di SMA Xaverius Lubuklinggau Tahun Pelajaran 2016/2017. STKIP-PGRI Lubuklinggau: Sumatra Selatan.

Fitriah, L. (2017). Diagnosis Miskonsepsi Siswa pada Materi Kalor dengan Menggunakan 
Three-Tier Essay dan Open-Ended Test Items. Berkala Ilmiah Pendidikan Fisika, 5(2), 168-181.

Ismail, I. I., Samsudin, A., Suhendi, E., \& Kaniawati, I. (2015). Diagnostik miskonsepsi melalui listrik dinamis four tier test. Prosiding Simposium Nasional Inovasi dan Pembelajaran Sains, 381-384.

Kawuri, M. Y. R. T., Ishafit, I., \& Fayanto, S. (2019). Efforts to improve the learning activity and learning outcomes of physics students with using a problem-based learning model. IJIS Edu: Indonesian Journal of Integrated Science Education, 1(2), 105-114.

Kusairi, S., \& Zulaikah, S. (2017). Diagnosis miskonsepsi siswa SMA di Kota Malang pada konsep suhu dan kalor menggunakan three tier test. Jurnal Pendidikan Fisika dan Teknologi, 2(3), 95-105.

Muna, I. A. (2016). Identifikasi Miskonsepsi Mahasiswa PGMI Pada Konsep Hukum Newton Menggunakan Certainty of Response Index (CRI). Cendekia: Jurnal Kependidikan Dan Kemasyarakatan, 13(2), 309-322.
Nasafi, I. (2018). Pengembangan instrumen tes diagnostik pilihan ganda tiga tingkat untuk mengidentifikasi miskonsepsi siswa pada materi hukum Newton (Doctoral dissertation, UIN Walisongo).

Rahmawati, D., \& Wiyono, K. Syuhendri. 2017."Analisis Pemahaman Konsep Termodinamika Mahasiswa Pendidikan Fisika Menggunakan Instrumen Survey of Thermodynamic Process and First and Second Laws (STPFaSL).". Jurnal Ilmu Fisika Dan Pembelajarannya, 1(1), 17-27.

Suparno, P. (2005). Miskonsepsi dan Perubahan Konsep Dalam Fisika. Universitas Sanata Dharma: Yogyakarta.

Suwarna, I. P. 2013. Analisis Miskonsepsi Peserta Didik SMA Kelas X pada Materi pelajaran Fisika Melalui CRI (Certainly OF Response Index) Termodifikasi. Jurnal Laporan Lemlit Analisis Miskonsepsi.

Zulvita, R., \& Halim, A. (2017). Identifikasi dan remediasi miskonsepsi konsep hukum newton dengan menggunakan metode eksperimen di man darussalam. Jurnal Ilmiah Mahasiswa Pendidikan Fisika, 2(1), 128-134. 